\title{
Beg, Borrow, or Steal: \\ Determinants of Student Academic Misconduct in Higher Education
}

\author{
Elena Denisova-Schmidt \\ University of St. Gallen (HSG), Switzerland \\ Fellow of Boston College Center for International Higher Education (CIHE) \\ elena.denisova-schmidt@unisg.ch \\ Yaroslav Prytula \\ Ukrainian Catholic University, Ukraine \\ ya.prytula@ucu.edu.ua \\ Nataliya L. Rumyantseva ${ }^{\text {a,b }}$ \\ University of Greenwich, UK \\ $\underline{\text { Rn32@gre.ac.uk }}$
}

\begin{abstract}
Actions underpinned by the lack of academic integrity are increasingly impacting academic processes within the higher education sector around the world. Bribery, plagiarism and other forms of deception that enable students to obtain undeserved grades or degree certificates undermine the purpose and mission of higher education. By drawing on a large dataset obtained through face-to-face interviews with students in Ukraine, this paper explores the determinants of several forms of students' academic misconduct and provides insights as to which groups of students are more likely to engage in either monetary or non-monetary corruption - information that will be of interest to educators, policymakers and other practitioners.
\end{abstract}

Keywords: Corruption, Academic Integrity, University, Students, Ukraine. 
This study was conducted with financial support provided by the Center for Governance and Culture in Europe at the University of St. Gallen and the Department of Economics at the University of Fribourg. The sponsors influenced neither the research design nor the interpretation of the results. The preliminary findings were discussed at the Comparative Education Society Europe (CESE) conference, May 31 - June 3, 2016, Glasgow, United Kingdom; the Southern Economic Association (SEA) 86th Annual Meeting, November 19-21, 2016, Washington (DC), United States; and the Annual Project Conference: Transnational Contact Zones: Redefining Ukrainian Regionalism, September 14-16, 2017, Odessa, Ukraine. The authors are thankful for all of the feedback they received during these events.

${ }^{a}$ Corresponding Author Nataliya Rumyantseva (N.Rumyantseva@greenwich.ac.uk), Business School QA 159, University of Greenwich, Park Row, Greenwich, London, SE10 9LS, UK

Elena Denisova-Schmidt (elena.denisova-schmidt@unisg.ch), University of St. Gallen (HSG), Gatterstr. 3, 9010 St. Gallen, Switzerland

Yaroslav Prytula (ya.prytula@ucu.edu.ua), Ukrainian Catholic University vul. Ilariona Sventsitskoho, 17, 79011 Lviv, Ukraine,

b Authors' names are presented in the alphabetical order and all authors contributed equally to this paper 


\section{Introduction}

The massification of higher education around the world, although enabling access and social mobility, has been accompanied by number of negative trends that change the purpose and nature of the educational experience (Trow, 2000, Heyneman, 2013, Altbach, 2016). One such trend has been a growing lack of academic integrity or a rise in academic misconduct directly impacting educational processes and outcomes. As the demand for university degrees expanded, so did the instances of acquiring them through illicit means by engaging in cheating, bribery and other forms of academic misconduct. Although student cheating is not new in higher education (Barnes, 1904), like education itself it has become more widespread in the recent past The growing body of evidence shows that few countries, whilst preserving commitment to developing the young, have manage to escape the phenomenon of academic corruption in higher education (Hallak and Poisson, 2007, Sweeney, Despota, and Lindner, 2013, Bretag, 2016, and Denisova-Schmidt 2018a).

Mirroring the growth in academic misconduct, the academic literature on this phenomenon has been steadily increasing in quantity and in the degree of analytical value since the 1990s (e.g. Chapman and Linder, 2016). Topics covered in the literature range from debates on definitions (Reybold, 2008) to examples and illustrations (Poore-Pariseau, 2009) to situational and environmental factors (Macfarlane and Ottewill, 2004). Some contributions have attempted to debate the students' perceptions of the academic staff's behaviour (and Kidwell, 2008), while others have focused on how the staff themselves perceive matters of ethical conduct (Aultman, Williams-Johnson, and Schutz, 2009). Artino and Brown (2009), for example, explored how the students' perceptions compare to those of academic staff. Yet very few studies have made attempts to investigate the determinants of academic misconduct in an empirical and systematic manner (for exceptions see Armantier and Boly, 2011 and, Katsaiti and Pecoraro, 2015).

In part, such an omission is to be expected, given that, by its very nature, misconduct is secretive and therefore can be difficult to study empirically. What leaves no doubt is that it is a complex phenomenon that occurs within equally multifaceted systems of social networks and organisational structures (e.g. Rumyantseva and Denisova-Schmidt, 2015 for a Russian illustration). Despite existing efforts to understand the mechanics of bribery, cheating on exams and intentional plagiarism in practical and useful ways, much remains to be explored with regard to the antecedents to the deviant ways of acquiring grades or gaining admission to university. Looking into the antecedents of corruption would not only lay out empirically based foundations for anti-corruption policies, but also provide a window into understanding the contributions of the relevant agents and pave more specific pathways for attempts to shift entrenched negative behaviours (Denisova-Schmidt, 2018b). As above 
mentioned studies suggest, corruption is everyone's problem when it comes to higher education. Academic staff, students and institutions and even publisher producing readymade crib sheets all add into the pot. For analytical purpose, this paper focuses on the student side of the educational equation, whilst we remain (and invite the reader to do so) mindful of the contribution from the side of other critical stakeholders. Engaging with the student data, we explore the driving factors of the stakeholders who should be most interested in acquiring knowledge and skills for their development and future employment. The intention is to illustrate pathways for empowering and less punitive anticorruption measures. Focusing on corruption as a behaviour of interest, we inevitably separate students into more or less inclined to engage with it, thus also highlighting pockets of integrity and moral courage.

Educational corruption knows no borders. Many developing and developed countries struggle with it (e.g. Hallak and Poisson, 2007). The empirical data for this particular study comes from Ukraine. Ukraine is interesting example for the study of educational corruption because it combines the status of one of the most corrupt countries worldwide as suggested by the Corruption Perceptions Index, regularly published by Transparency International (TI, 2017) with high levels of awareness and dissatisfaction with long-standing problems of corruption, which is often conceptualised as a mechanism of social injustice. Since gaining its independence from the USSR in 1991, Ukraine has undergone two revolutions: the 2004 Orange Revolution and the 2014 Revolution of Dignity, also called the 'Euromaidan' uprising. In both cases, the primary catalyst was a popular desire to fight corruption and, in both cases, students were among the main driving agents. The students' view of corruption within universities, hence becomes a particularly interesting focus for exploration. Why do students participate in corruption? Do they actively contribute? What drives them to accept and/or engage in corruption in their immediate surroundings? Does academic corruption have multiple functions (Denisova-Schmidt, 2018c)? What can be done in order to mitigate academic misconduct and malpractices with direct student involvement (Rumyantseva, 2005)?

The article is organized in the following manner: in section 2, we discuss selected studies that explore the antecedents of corruption in higher education and other sectors. In section 3 , we describe the data set, variables and rationale. Section 4 presents the econometric estimation and study outcomes. Section 5 discussing the finding and their implications for anti-corruption initiatives in universities. 


\section{What is academic corruption and what drives students to engage in it?}

The terms academic misconduct, plagiarism and academic corruption are often used to describe various forms of secretive, although sometimes also very open but still deviant, dishonest behaviours in the academic context that have damaging consequences for social institutions and society at large. The literature on corruption shares a common struggle to define the term in a manner sufficiently comprehensive to be meaningful and yet sufficiently specific to remain practical. Chapman and Linder (2016) offer an accurate summary of such debates in higher education literature. Transparency International (2017) defines corruption as 'the abuse of entrusted power for private gain'. But what of the corruption initiated by students who do not hold entrusted power or a public office? Heyneman's (2013) definition of corruption as ‘the lack of academic integrity' covers these types of behaviour but remains murky on what constitutes academic integrity. Van Duyne (2001) offers a more dynamic definition that refers to the deterioration of the process of decision making. Specifically, he sees corruption as 'an improbity or decay in the decision-making process in which a decision-maker consents to deviate or demands deviation from the criterion which should rule his or her decision-making, in exchange for a reward or for the promise or expectation of a reward, while these motives influencing his or her decision-making cannot be part of the justification of the decision' (Van Duyne, 2001, p. 3). A combination of these definitions enables us to use the terms 'corruption' and 'the lack of academic integrity' interchangeably (Denisova-Schmidt, 2018a). Referring to the context of higher education, Chapman and Linder (2016) provide multiple illustrations of corruption, which include plagiarism; exam briber, cheating, and seeking preferential treatment. The empirical part of this paper is focused on these forms of behaviour as our key dependent variables, separating them in to groups: monetary academic (bribery for grades) and nonmonetary academic corruption (deviant ways of obtaining grades without resorting to money).

Why do some individuals choose corruption over honest dealings while others do not? What explains the variation in the degree of students' engagement with bribery and other non-monetary forms of cheating? Researchers in various disciplines have explored this question in some detail, relying on experimental design. These studies help us understand the role of internalised factors (social norms and culture) (e.g. Barr and Serra, 2010) and external conditions, such as expected payoffs and foreseeing risks of getting caught (e.g. Armantier and Boly, 2011) in predicting corrupt decisions. A natural experiment reported by Fisman and Miguel (2007) focuses on the parking behaviours of United Nation officials in Manhattan before and after enforcement authorities acquired the right to confiscate the diplomatic license plates of violators. Although the diplomat's country of origin was a strong predictor of their poor parking behaviours and disregard for parking tickets initially, this relationship disappeared after legal enforcements have been introduced. 
Empirical studies that look specifically at the antecedents of academic misconduct in the context of higher education are fewer ( for exception see Curtis and Vardanega, 2016). Literature in this area has concentrated on explorations of perceptions and discussions of the ethical norms and duties of academic professionals. An assumption is often made that corrupt exchanges are driven by academics, and the students are victimised as a result. Evidence suggests that the initiators of bribes may be lecturers, either indirectly or directly (Denisova-Schmidt, Huber and Leontyeva, 2016a). In many instances, however, the initiators of misconduct in general and bribes more specifically are the students themselves. Shaw, Katsaiti and Pecoraro (2015) note that 'students may participate in such mutually beneficial agreements if they believe better performance in education opens doors toward better job opportunities' or to preserve self-image. Barr and Serra's (2010) UK based experimental study of international students has concluded that cultural norms and values of the country of origin have a strong influence on undergraduate students' decision to bribe. This link however disappears for the post-graduate students. These authors also conclude that the longer international students stay in the UK, the weaker is their propensity to bribe. Hence, they raise the need to consider individual difference and avoid cultural stereotyping. Shaw, Katsaiti and Pecoraro's (2015) study draws on a culturally homogenous (Ukrainians) student data and in confirmation of the Barr and Serra's conclusion shows considerable individual variation in the levels of academic bribery. The differences are explained by students' perceptions of corruption around them, past bribing behaviours and perceived criminality of corruption.

In this paper, we build on the work of Shaw, Katsaiti and Pecoraro (2015) by considering bribery and six different types of non-monetary corruption as our outcome variables. Similar to the authors, we seek to establish the degree of influence of corruption perceptions and personal values. We further expand our considerations by including perceptions of the fairness of the job process, and the degree of perceived usefulness of higher education studies for equipping one for a job. We introduce the size of the city of origin to capture the possible impact of social networks where a student was raised. We introduce measures of practical constraints that can limit students' ability to earn good grades: limited time, money, noise free study space. We also seek to recognise potential enablers that empower students to earn honest grades: hours spent on self-study and prior and current academic achievements. A combination of constraints and enablers may to some degree explain academic corruption as a survival strategies for the students. Such detailed analysis of the cultural homogenous dataset allows for more nuanced understanding of the drivers of student engagement in corruption and hence, pinpoints the areas for well-focused anti-corruption interventions. 


\section{Research Design and Data}

Our empirical study was conducted in the spring of 2015 at selected public universities in Lviv. Lviv is a major city in the western part of Ukraine, a region with a low level of corruption in comparison to other regions in the country (Denisova-Schmidt and Huber, 2014; Foster, 2015; Denisova-Schmidt, Huber and Prytula, 2015). Lviv is home to 26 universities; our representative analysis was conducted at four of them. A total of 600 students participated in the study. Both genders were represented almost equally, with $42.2 \%(\mathrm{n}=253)$ female students and $57.8 \%(\mathrm{n}=347)$ male students (Table 1$)$. The participating undergraduate students were all approximately the same age (19-20 years). Students were approached by the interviewer on their home campus. The specially trained interviewers engaged students in face-to-face, semi-structured interviews and asked them to fill out a questionnaire afterwards. The quantitative part of this data collection process serves as the basis for the current paper. The study was conducted completely in Ukrainian, the native language of all the persons involved. No language-based misunderstandings are expected. The sample includes only respondents studying at public universities in four main areas: social, natural and technical sciences and the humanities, representing a majority of all students (Table 1). We considered only students studying at public universities on-site with at least three to five prior semesters (2-oi kurs or 3-ii kurs). Table 1 presents the descriptive statistics of independent variables. Table 2 provide means and standard deviations for measures of non-monetary corruption and Table 3 for bribery or monetary corruption.

\section{TABLE 1 ABOUT HERE}

\section{$\underline{\text { Dependent variables }}$}

A Likert-type scale of ordinal variables ranked "never", "rarely", "sometimes", "often" and "always" was used to measure students' personal experience with the following examples of dishonest behaviours aiming at improving one's grades: monetary corruption, namely bribery; and non-monetary corruption, namely using a cheat sheet during the exam, downloading coursework from the internet, buying coursework from the special agency, copying some parts of a course paper from the Internet, copying somebody's work during exam or test, resorting to emotional manipulation while explaining problems associated with studies, lying to a tutor about extenuating circumstances relevant to a piece of assessment. Descriptive statistics on frequency of personal experience and perception of such behaviours can be found Table 1 . 


\section{Independent Variables and Hypotheses}

Perceptions of the issue: Previous research has shown that people who believe that everyone around them is corrupt are more prone to corruption and cheating (John, Loewenstein, Rick, 2014; Corbacho et al. 2016, Denisova-Schmidt, Huber Prytula, 2015 and Denisova-Schmidt, Huber and Leontyeva, 2016a). A study by Shaw, Katsaiti and Pecoraro (2015) found that perceptions of the corruption of others has had a positive impact on personal involvement of students in Ukraine. Hence we included several questions about the respondents' perceptions on monetary and non-monetary corruption of other people at school, during university admission and in everyday life. The same methodology of defining students' perceived corruption was used in Denisova-Schmidt, Huber and Prytula (2015).

Formal ways of job search : Similar to the above, students who believe that job search and selection process is based on merit will be less prone to engage in deception and choose to study instead of gain knowledge and skills necessary. Using a 5-point Likert scale, we asked students to rank the extent to which they believe in the merit based nature of the job search process in the country.

Negative attitude towards corruption: In the Western world corruption is often defined as deficient morality (De Vries and Kim, 2011) and calls for virtuous values as the means of eradicating it. Although the correspondence between values and actions is not straightforward, we hypothesise that students who view corruption negatively are less likely to engage with it to avoid the state of cognitive dissonance resulting from acting against one's convictions. In this study students have been asked to indicate their personal stance in relation to corruption and other dishonest behaviours by choosing between negative view and several other more positive or pragmatic positions (e.g. corruption as problem solving). 'Negative' has been coded as 1 to generate a dummy variable, positive and pragmatic views are the reference group.

HiEd helps to get good education and good job: Students who believe that studying generates valuable knowledge relevant to future employment will be more inclined to earn their grades rather than engage in academic corruption. We have asked students to choose the primary reason for choosing university studies over other professional paths. 'Good education and good job' was coded as 1 with all other reasons forming a reference group.

Gender: Several studies showed the impact of gender on corrupt behaviour. This usually ranged from 'good girls' and 'bad boys' (Swamy, et. al. 2001; Jetter and Walker, 2015, and Dimant and Tosato, 2017) to (rarely) significantly active female bribe-givers. The study by Shaw, Katsaiti and Pecoraro (2015), for example, suggests that female students show a higher propensity to bribe during exams at universities. Our sample includes 'gender' as one of the variables, with 'males' coded as 1.

State Scholarship: higher education finance is Ukraine follows the binary system, where a small quota of academically better performing students is admitted on full scholarships as opposed to remaining 
applicants who are entirely responsible for their tuition fees and living expenses (Erfort, Erfort and Zbarazskaya, 2016). Students who receive such state scholarships, although academically better able are also under constant pressure to maintain a required level of performance. This pressure may create an additional incentive to resort to deception or bribery as a problem solving tool, all other factors being equal. Hence, our dataset contains 'state scholarship' variable coded as 1 .

Level of Wealth: Studies show that some people are not involved in various types of corruption because they do not have the resources and cannot afford any additional payments and/or they do not know how to initiate them (Denisova-Schmidt, 2014). In our dataset, wealth is represented by two variables: income status of the family and students' monthly expenditure. We capture the Income Status of the Family by four dummy variables: 'enough money for food only', 'enough money only for food and clothes', 'enough for food and clothes is available, but purchasing durable items might be problem', 'enough for purchasing durable goods, but purchasing very expensive items like apartments or cars might be a problem'. The reference group is 'can afford almost anything'. Monthly expenditure (housing not included) is measured by three dummy variables: 'less than 1000UAH', 'between 1000UAH and 1600UAH' and 'between 1600UAH and 2000 UAH'. 'More than 2000 UAH is a reference group'.

Type of Living Accommodation: Of a particular interest here are students who live in dorms. In the Ukrainian context in particular, these experience higher level of day to day challenges and practical inconveniences with their studies. Dormitories tend to be noisy without suitable study areas and several students usually share a room. This can affect one's ability to concentrate and find quiet place/time to study. Moreover, such places are also very social and any information as well as value based attitudes with regards to corrupt practices spread easily. Access to such information may be fuelling students' acceptance of such practices and offer practical guidance on how to go about offering a bribe or not getting caught whilst cheating. Hence, we hypothesize that students who live in dorms will be more prone to report personal engagement with academic corruption. In our data set this construct is captured by two dummy variables: 'living in dormitory' and 'living with parents', whilst 'rent a flat' remains a reference group.

Academic Performance: Higher education offers a special social status and the potential of security of a professional future in Ukraine. The social pressure to obtain a degree is high. As a result, about $80 \%$ of young Ukrainians go to universities and almost all of them get their degree on time (Bastedo et. al., 2009; Denisova-Schmidt, Huber and Leontyeva, 2016a). Not all of them are ready to study on such a high level, however, and corruption is one of the ways for them to survive the academic pressures. Hence we added the two variables 'external independent evaluation results' that measures academic performance before admission and 'performance during university studies'. External 
independent evaluation or $Z N O^{l}$ results in Ukrainian, are represented by 3 dummy variables: 'below 500', '500-600', '600-700' with 'above 700’2 being the reference group. Performance during university dummies cover four categories: 'satisfactory', between 'satisfactory' and 'good', 'good'; between 'good and excellent' with 'excellent' being the reference group.

Part-time work: Longer working hours introduce barriers to study, hence corruption may look like an attractive solution to the dilemma it introduces. In Ukrainian higher education, study programmes tend to be overloaded with contact hours and high expectations of drill type and memorisation learning. Due to long existing traditions that emphasise face to face contact with students, the latter are expected to spend as much as 15 or more hours in the classroom, taking more than 5 subjects at any given term and expected to do regular homework on all of them. Those students who work parttime are more likely to cut corners through bribing and cheating due to time constraints. In fact, students in Russian universities report exactly these reason when asked why they engage in academic misconduct (Denisova-Schmidt, 2013). This construct is measured by three dummy variables: 'do not work, 'less than 4 hours' and 'between 4 and 6 hours'. 'Over 6 hours' is a reference group.

Time spend on studying: Time a student spends on studying is indicative not only of the amount of effort and dedication he or she puts into their own learning but also a level of receptivity towards the types of learning that are expected of them as well as their assessment of the level of expectations as achievable. Hence, students who spend more time on independent study will be less prone to engaging with academic corruption. On the other hand, students who don't spend time on studying but still desire to pass, will be more inclined to 'solve the problem' through dubious means. This aspect of academic corruption is studies in more detail in the empirical study of Russian students (DenisovaSchmidt and Leontyeva, 2013). This construct is captured by four dummy variables: 'none', 'less than 1 hour', '1-2 hours', $-2-3$ hours', with 'more than 3 hours per day' being a reference group.

Size of the city of origin: Cabelkova and Hanousek (2004) suggested initially that the size of the city of origin in Ukraine should have an impact on individual students' propensity to engage with

\footnotetext{
${ }^{1}$ Zovnishnie Nezalezne Otsinjuvannia (ZNO) (Engl.: External Independent Assessment) - a test that serves as both secondary school finals and university admission exams.

${ }^{2} \mathrm{ZNO}$ results come of four sources: three subject tests plus an average mark from the secondary school. Each source can give minimum 100 and maximum 200 points, that is, the ZNO result lies between 400 and 800 . Some additional points (up to 10 points) can be given for the winners of the all-Ukraine pupil Olympiads or similar competitions, however the number of such entrants is very limited. ZNO results below 500 can be treated as very low; results between 500 and 600 are also considered as quite low results with almost no chances to get state placement or stipend; results between 600 and 700 are considered good results with good chances to get state placement or stipend; results above 700 can be treated as excellent and, as a rule, give very high chances to get state placement or stipend.
} 
corruption. Specifically, larger cities with their anonymous atmosphere would be producing more corrupt individuals, whereas small cities would be containing of such behaviours due to the system of checks and balances. However, Shaw, Katsaiti and Pecoraro (2015) have found their empirical evidence to contradict this with smaller cities having more of an effect on individual students' propensity to get involved with corruption. Viewing corruption through the theory of collective action (Marquette and Peiffer, 2015) helps explain this disagreement. Larger cities in Ukraine tend to be more cosmopolitan and on average more educated population would be better equipped to deal with problems and interact with strangers without having to resort to dubious measures. Whereas, smaller cities and villages represent more tightly knit networks, with people being more aware of each other's shortcomings which are compensated by the use to of favours. Hence, we hypothesise that students from smaller municipalities are more likely to bring their corrupt habits of problems solving to their education process. This construct is captured by five dummy variables: 'more than $1 \mathrm{mln}$ ', 'city 0.5 to $1 \mathrm{mln}$ ', 'city 0.25 to $0.5 \mathrm{mln}$ ', 'city 0.05 to $0.25 \mathrm{mln}$ ', 'city 0.02 to $0.05 \mathrm{mln}$ ', 'small city', with the smallest 'village' being a reference group.

\section{Methods and results}

\section{Descriptive Statistics}

Table 1 presents means and standard deviations for the eight dependent variables. The most frequently used forms of academic corruption in our dataset are: using a cheat shit during exams (mean=3.48), copying someone else's work during exams (mean=3.44) and copying chapters from the internet when writing papers (mean=3.26). The average frequency of encounters with bribery is not very high but noticeable $($ mean $=1.81)$.

Table 2 presents means and standard deviations for all scale independent variables. Perception of all types of academic corruption is noticeably higher than the reported personal experience. The leading suspects, however, remain the same: using a cheat shit during exams (mean=4.18), copying somebody else's work during exam (mean=4.07), and copying chapters from internet when writing a paper (mean=3.91). The perceived frequency of bribery is 3.5, higher than the reported experience of 1.81 . Students believe that formal (non-corrupt) ways of job search can yield a job is fairly strong in our data at the mean level of 3.49 .

Table 3 contains frequencies for the independent categorical variables. Our sample contains more men $(57 \%)$ than women and $71 \%$ of all students received state scholarships. $70 \%$ of students live in 
dorms and $54 \%$ view corruption as a negative social phenomenon. Over $80 \%$ of students have a hopeful view of education as a process that is conducive towards improving oneself and one's chances of a good job. Yet only $15 \%$ undertake more than 3 hours per day of independent study. Over $60 \%$ report studying between 1-3 hours. The most frequent average grade is good (32\%) and between good and excellent (35.8\%). 89\% reported having very high ZNO scores from 600 upwards. 51\% of the sample claim their families have enough income to afford durable goods without difficulties. Yet nearly $80 \%$ of students claimed that they spend under $1600 \mathrm{UAH}$ on monthly basis. Most students don't work during their studies (77.2\%). 11.7\% claim working between 4 and 6 hours a day.

\section{Regression}

We performed the logistic regression analyses based on regression models with ordinal variables. The use of linear regression with an ordinal categorical dependent variable violates the continuity and normality of dependent variable assumptions and causes the analysis to lose some important information, which could lead to ambiguous results. The explicit recognition of the ordinality of the dependent variable and the usage of ordinal regression helps to analyse different types of variables (continuous, dichotomous and ordinal) within a common statistical framework and to avoid arbitrary assumptions about the scale of the variables (Winship and Mare, 1984). The estimation results are shown in Table 2.

As predicted by existing literature, (at the $1 \%$ level of significance) students' perception of prevalence of corruption around them has a strong positive effect on the level of their personal experience with all the types of academic misconduct. Students who believe job search process is based on merit show less personal experience with bribing, 'using a cheat sheet during the exams', 'downloading coursework from the Internet' and 'copying somebody's work during examinations or tests'.

\section{TABLE 2 ABOUT HERE}

Those students who have negative attitudes toward corruption, have less experience with all types of academic misconduct. This result is statistically significant for bribing, 'copying some parts of a course paper from the Internet', 'copying somebody's work during examinations or tests' and 'asking a professor for individual treatment'. Students who believe that higher education leads to good education and good job are not different from the rest of the students when it comes to participating 
in academic corruption. Male students in our dataset were on average more likely to use unauthorized materials during exams, buy coursework from special companies or classmates, encounter bribes (all significant at the $1 \%$ level) and cheat by downloading coursework from the internet, deceive a professor about problems associated with studies or ask them for a preferential treatment (at the 10\% level). The living arrangement is significant in determining some type's of students' misconduct: those who live in the dormitories are more likely to encounter bribes (significant at the $10 \%$ level) and use unauthorized materials during exams (significant at the $1 \%$ level). Students' pre-admission academic performance (ZNO exams) has yielded mixed results. Contrary to the expected, students in the middle range of ZNO test scores (between 600 and 700) show highest levels of personal experience with bribery and buying coursework (statistically significant at 5\%) and using crib sheets during exams (significant at 1\%). Students with lower ZNO scores (between 500 and 600) show higher levels of personal experience with plagiarising parts of assignments using internet (significant at $10 \%$ ). However, on the whole, ZNO scores make little different to the levels of students' personal experience with corruption. Academic performance, whilst in the university has a stronger and closer to expected impact on experience with most types of corruption, except for bribery. Students who perform at 'satisfactory' level report statistically significant levels of involvement with all seven forms of non-monetary corruption. Students at 'between satisfactory and good' and 'good' levels report involvement with four types of non-monetary corruption (using a cheat sheet during exams, downloading coursework off the internet, deceiving a professor or asking them for a preferential treatment). Students at 'between good and excellent' show a similar pattern with the exception of deceiving professors.

Time investment into independent study makes a considerable difference to the degree of students' personal experience with corruption. Students who spend between zero and one hour on self-study per day report higher levels of involvement with nearly all forms of corruption. Students who spend between 1-3 hours on independent study are less involved with fewer types of misconduct than the entirely idle groups. On the whole is it clear that students who invest time into studying don't need to resort to either bribing, cheating or plagiarism nearly as much. The importance of time is once again confirmed with the results for the part-time work. Students who do not work or work under 4 hours a week have less experience of corruption in terms of 'using a crib cheat during exams' (significant at the 10\% level) and 'downloading coursework from the Internet' (significant at the $1 \%$ level) compared to those who have a high working load (6-8 hours).

As a rule, we do not find a strong relationship between students' family wealth and academic misconduct. No one category of income status of the family differs significantly in its relation to any kind of academic dishonesty. Also, the categories of students' spending status do not differ 
significantly in their relation to academic dishonesty. The exception are the cases of 'using a crib cheat during exams', 'copying some parts of a course paper from the Internet' and 'copying somebody's work during examinations or tests', where lower spending (less than 1,000 UAH and between 1,000 and 1,600 UAH) indicate lower personal experience in corresponding type of academic dishonesty (at the $5 \%$ level of significance). Students from large cities (with a population of 1 million and above) indicate less academic dishonesty than students from villages for all dependent variables, although the results are not always statistically significant. .

\section{Discussion}

The growth and diversification of higher education systems around the world has been accompanied by increasing practices of academic corruption enacted, promoted but also resisted by various stakeholders of the academic process (Hallak and Poisson, 2007, Sweeney, Despota, and Lindner, 2013, Bretag, 2016). This study makes a contribution to a small but growing body of literature (e.g. Shaw, Katsaiti and Pecoraro, 2015) that explores the driving factors of academic corruption practices form the student side of the educational equation. The focus on the students' involvement does not downplay or negate the contributions that other stakeholders inevitably bring to the table by either demanding bribes, colluding or turning a blind eye onto student plagiarism. Instead it recognised that students are equal actors of the educational process and have their own motivations and constraints that contribute to their decision to engage or abstain/resist corruption behaviours. Understanding students' views and specific circumstances facilitates development of anti-corruption measures that would empower the students to actively join the anti-corruption movement and building of the culture of academic integrity.

The outcomes of the study demonstrate that complex interplay between personal values, perceptions of actions of others and practical pressures and constraints all play a role in student engagement with academic corruption to a different extent. As the shadow cannot exist without the light, corruption co-exists side by side with student self-restraint and active resistance to cheating and deception. The national context of Ukraine in this study is of a particular significance, as Ukraine is recognised as a highly corrupt country (TI cite) on the one hand, but also the country that has actively and visibly struggled against corruption in the recent years (Halushka, 2018). However, given high levels of academic misconduct and student mobility worldwide they are equally relevant to societies beyond the post-soviet landscape. Together with understanding of what contributes to students' involvement, this study localises pockets of integrity that can and should be harnessed for constructive anticorruption action. The recent research on anti-corruption approaches suggests that it may be more efficient to focus on fighting specific types of malpractices rather than generalized corruption itself 
(e.g. Shekshnia, Ledeneva, and Denisova-Schmidt 2017; Denisova-Schmidt, 2018b). To understand the specifics we have asked the question: what drives/constraints student engagement with seven forms of academic corruption? We discuss our findings along with the policy implications in the 4 sections below.

\section{Values and perceptions}

Our study echoes previous findings that connected perception of corruption of others with individual levels of engagement (John, Loewenstein, Rick, 2004, Corbacho et al. 2016, and Shaw, Katsaiti and Pecoraro, 2015). Observing their relatives, friends, teachers, politician's self-serving and nontransparent actions, students adopt these behaviours for themselves. However, personal values that mark corruption as negative have a constraining effect on student engagement with all types of academic misconduct, a link previously established by Shaw, Katsaiti and Pecorar (2015) for student bribing behaviours. Combining anti-corruption initiatives that seek to influence collective perceptions of existing levels of corruption with educational approaches advocated by Wood and Antonowicz (2011) have the power to transform student engagement with academic corruption. What is more, such efforts can be actively identifying and drafting students who already have negative view of corruption to become stewards of academic integrity in a peer to peer format. Similarly to Shaw, Katsaiti and Pecorar (2015), the current study identifies students from larger cities as less prone to engagement with various forms of corruption, likely reflecting the cosmopolitan values and looser social networks. University administrators and policy makers can further draw on this student population when crafting programmes that promote academic integrity. The findings remain mixed with regards to gender with Shaw, Katsaiti and Pecorar (2015) reporting female students as the major suspects, whereas the present study is more in line with previous 'good girls'/'bad boys' conclusions (Swamy, et. al. 2001; Jetter and Walker, 2015; and Dimant and Tosato, 2017) It is therefore, advisable not to rely on gender alone when identifying potential stewards of integrity.

Such value driven and perception based initiatives, however are unlikely to yield desired outcomes in their own right. By looking into student circumstances, this study expanded on the work of Shaw, Katsaiti and Pecorar (2015) and identified three groups of students that will benefit from additional financial investments, improved infrastructure and changes to the admissions process before they can be expected to give up dishonest behaviours. These include students who live in dorms, academically unprepared students and students who work over 6 hours a week.

\section{Dormitory living}

Students living in dormitories are more likely to resort to cheating than those who live with their parents or rent private accommodation. These students face harsher practical demands on their time 
due to the need to solve everyday problems (shopping, cooking, cleaning, etc.) and may have less time and energy for studying. Many dormitories worldwide and in Ukraine specifically do not guarantee quiet study spaces and instead students have to exist in a perpetual party universe. Material investments in the infrastructure are needed to make dorms conducive to the academic culture. The flipside of the social nature of dorm living is that these are probably the best-informed students when it comes to possible cheating techniques. Equally, however, dorms can be converted into fruitful hubs for spreading positive individual values around integrity and creative subcultures that take pride in honest academic work. Hence, to re-set the negative cycle, re-configurations and improvements to the physical structures should be accompanied by infusion of values of higher academic integrity, honesty and negative conceptualisations of corruption.

\section{Engaging in self-study}

Students who spend little time on self-guided study are more likely to use various cheating techniques. Pressures of academic demands at the university generate a survival need through quick-fix solutions offered by cheating and bribery. Many students consider university studies to be a pathway to a formal credential rather than a pursuit of knowledge (Polese at al., 2018). For many countries, more rigorous selection mechanisms, such as writing a statement of purpose, will weed out some of these students from the start. When recruiting international students, pre-selection stage might be partly outsourced and conducted in cooperation with domestic partners, as is currently being performed by the German Akademische Prüfstelle (APS, established in 2001) for students from China, Vietnam and Mongolia applying for a student visa in Germany, Austria, Belgium and Switzerland. Almost all student candidates undergo this procedure, which involves the verification of academic certificates and an interview on the field of study, as well as a fee (about 300 USD).

Frequent and surprise assessment can be used to remind students that they are expected to study regularly and thus boost their levels of academic engagement. At a broader policy level, continuing popularisation of the vocational track in the already very diverse higher education system in Ukraine specifically (Rumyantseva and Logvynenko, 2018) provides an alternative outlet for students who are less comfortable with more rigorous demands in higher education. The academically stronger students can be drafted into part-time employment as academic engagement champions to inspire and motivate those who struggle. With adequate preparation and training, such mini partnerships may not only spread academic knowledge but also promote positive attitude towards studying and negative views of those who undermine these efforts through cheating. In addition to these progressive measures, anti-plagiarism anti-bribery discussions should be a mandatory part of a university's introduction week and/or should be integrated into the curriculum for all incoming students. These types of courses have the capacity to increase student awareness of academic integrity significantly, 
even in less corrupt countries like Australia (Curtis et al. 2013). Faculty members should be explicitly articulating their expectations in terms of academic integrity, acknowledging the diversity of academic and cultural backgrounds of their students and the need to come to a common denominator at the same time. The punitive measure, however, should be only used in a careful combination with more aspirational and developmental approaches to have a constructive developmental impact (de Jager and Brown, 2010).

\section{Working excessive hours}

One additional problematic group are the students who work over six hours per week. They are particularly likely to engage in non-monetary corruption. Previous research has documented a negative impact of part-time jobs on academic achievement (Salamonson and Andrew, 2006). Students in our sample, however, resort to cheating to boost their marks. This represents a difficult dilemma for both the universities and the students. Certain groups of students may not be able to afford studying without investing substantial amounts of their time into earning a living. Means tested scholarships or grants offered either by institutions or the governments would reduce some of the stress. Further academic counselling may be helpful to assist students with decision making and prioritising their studies.

Regardless of one's reasons for engaging in academic corruption, however, this phenomenon remains destructive and undesirable. To some extent and in the extreme cases public ostracism of the violators might be advisable: one Chinese student at Bath University in the United Kingdom who wanted to bribe his professor for a better mark brought 5,000 GBP and a loaded air pistol. The student was arrested, convicted and sentenced to jail in a story that was widely discussed in the media (University of Bath Student Jailed, BBC News, 2013). This example might be very instructive for other young people thinking of 'negotiating' marks via bribery.

\section{Conclusion}

Although corruption in higher education is common in many countries around the world, we do not know enough about factors that drive individuals to engage with it. This paper adds to the small body of literature that recognised the importance of individual variation depending on one's levels of corruption perception, moral stance on corruption and a series of practical constraints on one's time, living conditions that may or may not be conducive to studying, willingness to study independently, gender, and the size of city of origin. 
The findings are useful to scholars of academic corruption as well as policy makers in pointing out to pockets where interventions are most needed as well as pockets of integrity from which resources can be drawn to revert the culture of cheating and bribery.

\section{References}

Altbach, P. 2016. Global Perspectives on Higher Education. Baltimore: John Hopkins University.

Armantier, O. A. Boly, 2011. “A controlled field experiment on corruption”. European Economic Review, 55: 1072-1082, DOI:10.1016/j.euroecorev.2011.04.007

Armantier, O. and A. Boly. 2013. "Comparing Corruption in the Laboratory and in the Field in Burkina Faso and in Canada.” The Economic Journal 123: 1168-1187, DOI: 10.1111/ecoj.12019

Artino, A.R., and S.W. Brown. 2009. "Ethics in educational research: A comparative analysis of graduate student and faculty beliefs." College Student Journal 43 (2): 599-615, DOI:

$10.1080 / 03057640903354396$

Aultman, L.P., M.R. Williams-Johnson, and P.A. Schutz. 2009. "Boundary dilemmas in teacher-student relationships: Struggling with 'the line"'. Teaching and Teacher Education 25 (5): 636-46, DOI: 10.1016/j.tate.2008.10.002.

Barr, A. and D. Serra, 2010. "Corruption and culture: An experimental analysis," Journal of Public Economics. 94: 862-869, DOI: 10.1016/j.jpubeco.2010.07.006

Bastedo, M., Batkhuyag, B., Prates, E. and Prytula, Y., 2009. Educational Policies for Integrating College Competencies and Workforce Needs: Cases from Brazil, Mongolia, Ukraine, and the United States. Issue Brief. Institute for Higher Education Policy.

Bauhr, M. 2017. "Need or Greed? Conditions for Collective Action against Corruption." Governance, 30: 561-581. doi:10.1111/gove.12232 
Bretag, Tracey (Ed.) 2016. Handbook of Academic Integrity. Springer.

Č́belková, I. \& J. Hanousek 2010. “The power of negative thinking: corruption, perception and willingness to bribe in Ukraine", Applied Economics, 36(4): 383397, DOI: 10.1080/00036840410001674303

Cepic, D. 2013. Corruption in Higher Education and Research in Croatia. Paper presented at the Coping with New Legal Challenges in Education Conference, European Association for Education Law and Policy. Kaunas, Lithuania, September 13-14.

Chapman, D.W. and Linder, S., 2016. "Degrees of integrity: the threat of corruption in higher education." Studies in Higher Education, 41(2): 247-268, DOI: 10.1080/03075079.2014.927854

Corbacho, A. , Gingerich, D. W., Oliveros, V. and Ruiz-Vega, M. 2016. "Corruption as a SelfFulfilling Prophecy: Evidence from a Survey Experiment in Costa Rica." American Journal of Political Science, 60: 1077-1092.

Curtis, G.J. and Vardanega, L., 2016. "Is plagiarism changing over time? A 10-year time-lag study with three points of measurement." Higher Education Research \& Development, 35(6): 1-13. DOI $10.1080 / 07294360.2016 .1161602$

Denisova-Schmidt, E., 2013. Justification of Academic Corruption at Russian Universities: A Student Perspective. Edmond J. Safra Working Papers, (30).

Denisova-Schmidt, E., 2014. Institutional Performance and Social Values in Russia. EU: ANTICORRP, http://anticorrp.eu/publications/report-on-russia/

Denisova-Schmidt, E. 2016. "The Global Challenge of Academic Integrity." International Higher Education, 87: 4-6, ISSN 1084-0613

Denisova-Schmidt, E. 2018a. "Corruption in Higher Education". In Teixeira, P., Nuno and Shin, Jung-Cheol. (Eds). Encyclopedia of International Higher Education Systems and Institutions. Springer. 
Denisova-Schmidt, E. 2018b. "Corruption, the Lack of Academic Integrity and Other Ethical Issues in Higher Education: What Can be Done within the Bologna Process?" In The European Higher Education Area. Part III, Springer.

Denisova-Schmidt, E. 2018c. Corruption, BRIC Universities and the Effect on Global Higher Education: Causes, Techniques and Remedies. Basingstoke, New York: Palgrave Macmillan.

Denisova-Schmidt, E. and Leontyeva, E. 2013. "Do Russian Universities Teach their Students to be corrupt? Some empirical Evidence from the Far East." Educational Alternatives, 10 (3). 258275 , ISSN 1313-2571

Denisova-Schmidt, E. and Huber, M., 2014. "Regional differences in perceived corruption among Ukrainian firms.” Eurasian Geography and Economics, 55(1): 10-36, DOI: $10.1080 / 15387216.2014 .915757$

Denisova-Schmidt, E., Huber, M. and Prytula, Y. 2015. “An experimental evaluation of an anticorruption intervention among Ukrainian university students". Eurasian Geography and Economics, 56(6): 713-734, DOI: 10.1080/15387216.2016.1155467

Denisova-Schmidt E., Huber M. and Leontyeva E., 2016a. "Do Anti-Corruption Educational Campaigns Reach Students? Some Evidence from two cities in Russia and Ukraine”, Voprosy Obrazovaniia, 1: 61-83, DOI: 10.17323/1814-9545-2016-1-61-83

De Vries, M. S., and P. S. Kim. 2011. Value and Virtue in Public Administration: A Comparative Perspective. London: Palgrave Macmillan.

Dimant, E. and Tosato, G. 2017. "Causes and effects of corruption: What has past decade's research taught us? A survey.” Journal of Economic Surveys, 32: 335-356, DOI:10.1111/joes.12198

Erfort, O., I. Erfort and L. Zbarazskaya, 2016. "Financing higher education in Ukraine: The binary model versus the diversification model". International Journal of Educational Development, 49(C): 330-335, DOI: 10.1016/j.ijedudev.2016.03.009

Fisman, R. and Miguel, E., 2007. "Corruption, norms, and legal enforcement: Evidence from diplomatic parking tickets." Journal of Political economy, 115(6): 1020-1048, DOI: 0022$3808 / 2007 / 11506-0002$. 
Foster, H., 2015. Lviv becomes a model for development in Ukraine, USA TODAY, October 7 , 2015, Accessed at http://www.usatoday.com/story/money/business/2015/10/06/lviv-becomesmodel-development-ukraine/73335334/ on 1 February, 2016.

Gingerich, D.W., Oliveros, V., Corbacho, A. and Ruiz-Vega, M., 2015. Corruption as a SelfFulfilling Prophecy: Evidence from a Survey Experiment in Costa Rica. IDB Working Paper Series No. IDB-WP-546.

Golunov, S. 2014. The Elephant in the Room. Corruption and Cheating in Russian Universities. Stuttgart: Ibidem Verlag.

Hallak, J. and Poisson, M., 2007. Corrupt schools, corrupt universities: What can be done? International Institute for Education Planning.

Halushka, O. 2018. Ukraine's fight against corruption has started to work. Euobserver, Accessed on 20.03.2018 at https://euobserver.com/opinion/140946

Heyneman, S. P. 2013. "Higher Education Institutions: Why They Matter and Why Corruption Puts Them at Risk.” In G. Sweeney, K. Despota, and S. Lindner eds., Global Corruption Report: Education, Transparency International. Abingdon: Earthscan by Routledge, 101-108.

de Jager, K., \& Brown, C. 2010. "The tangled web: investigating academics' views of plagiarism at the University of Cape Town”. Studies in Higher Education, 35(5), 513-528, DOI: $10.1080 / 03075070903222641$

Jetter, M. and Walker, J.K., 2015. "Good girl, bad boy: Corrupt behaviour in professional tennis". Center for Research in Economics and Finance (CIEF), Working Papers, (15-04).

John, L., K., G. Loewenstein, and S. Rick. 2014. Cheating More for Less: Upward Social Comparisons Motivate the Poorly Compensated to Cheat. Organizational Behavior and Human Decision Processes 123: 101-109.

Macfarlane and Ottewill 2004. Macfarlane, B., and R. Ottewill. 2004. "A special context: Identifying the professional values associated with teaching in higher education." International Journal of Ethics 4 (1): 89-100. 
Morley, L. 2010. Sex, Grades and Power in Higher Education in Ghana and Tanzania. Cambridge Journal of Education 41: 101-115.

Pastra, Y. 2013. "Increasing Transparency and Enhancing Quality in Greek Higher Education.” In Global Corruption Report: Education, Transparency International, edited by G. Sweeney, K. Despota, and S. Lindner, pp. 133-37. Abingdon: Earthscan by Routledge.

Polese Abel, Tetiana Stepurko, Svitlana Oksamytna, Tanel Kerikmae, Archil Chochia, and Olena Levenets. 2018. Informality and Ukrainian higher educational institutions: Happy together? Policy Futures in Education, First Published March 13, 2018, https://doi.org/10.1177/1478210318758812

Poore-Pariseau, C.. 2009. Should faculty members be exempt from a mandate to receive instructional design training because of their rights under academic freedom? Journal of Academic Ethics 7, no. 3 (2009): 223-230.

Reybold, 2008. The social and political structuring of faculty ethicality in education. Journal of Innovative Higher Education 32: 279-95.

Roberts and Orttung (2015): Changing Corrupt Behaviors Assessment: Addressing Everyday Corruption in Ukraine. USAID. https://www.usaid.gov/documents/1863/changing-corruptbehaviors-assessment-addressing-everyday-corruption-ukraine

Rumyantseva, N. L. (2005) Taxonomy of corruption in higher education. Peabody Journal of Education. 80 (1), 81-92.

Rumyantseva, N. L. and Denisova-Schmidt, E. 2015. Institutional Corruption in Russian $\begin{array}{llll}\text { Universities. } & \text { International } & \text { Higher } & \text { Education, }\end{array}$ http://ejournals.bc.edu/ojs/index.php/ihe/article/view/8871

Rumyantseva, N. and Logvynenko, O. (2017) Ukraine: Higher education reforms and dynamics of the institutional landscape. In: 25 Years of Transformations of Higher Education Systems in PostSoviet Countries: Reform and Continuity. Palgrave Mcmilan.

Shaw, Katsaiti and Pecoraro. 2015. On the Determinants of Educational Corruption: the Case of Ukraine. Contemporary Economic Policy, 33 (4): 698-713.

Shekshnia, S, Ledeneva, A and E Denisova-Schmidt. 2017. Managing Business Corruption: Targeting Non-Compliant Practices in Systemically Corrupt Environments. Slavonic \& East European Review, 95, 1, 151-174, 2017.

Swamy, A., S. Knack, Y. Lee, and O. Azfar. 2001. "Gender and corruption.” Journal of Development Economics 64: 25-55. 
Sweeney, G., K. Despota, and S. Lindner. 2013. Global Corruption Report: Education. Transparency International, Routledge.

Teixeira, A. and M. Rocha 2010. “Academic Misconduct in Portugal: Results from a Large Scale Survey to University Economics/Business Students.” Journal of Academic Ethics 1 (8): 21-41.

Transparency International 2017. Corruption Perception Index. Accessed: https://www.transparency.org/cpi2013/results check link

Trow, 2000. From Mass Higher Education to Universal Access: The American Advantage. Research and Occasional Paper Series: CSHE.1.00 University of California, Berkeyley. Accessed: http://www.cshe.berkeley.edu/sites/default/files/shared/publications/docs/PP.Trow.MassHE.1.00.pd $\mathrm{f}$

Valentine and Kidwell, 2008. "Business students' ethical evaluation of faculty misconduct." Quality Assurance in Education 16, (3): 87-300.

Van Duyne, P. 2001. Will Caligula go transparent? Corruption in acts \& attitudes. Forum on Crime and Society, 1 (2): 73-98.

Winship, C. and R.D. Mare (1984). Regression Models with Ordinal Variables. American Sociological Review, Vol. 49. 512-525/ 
Table 1: Descriptive Statistics. Dependent variables.

Violation of academic integrity by personal experience in the following actions

(from 1 - never to 5 - systematically)

\begin{tabular}{|c|c|c|c|c|}
\hline Areas & Actions & $\begin{array}{c}\text { Observat } \\
\text { ions }\end{array}$ & Mean & $\begin{array}{l}\text { Standard } \\
\text { deviation }\end{array}$ \\
\hline $\begin{array}{l}\text { Non-monetary } \\
\text { corruption: }\end{array}$ & Using a cheat sheet during the exams & 599 & 3.48 & 1.14 \\
\hline Taking exams & $\begin{array}{l}\text { Copying somebody's work during } \\
\text { examinations or tests }\end{array}$ & 593 & 3.44 & 1.12 \\
\hline $\begin{array}{l}\text { Non-monetary } \\
\text { corruption: }\end{array}$ & $\begin{array}{l}\text { Downloading a course paper (or other written } \\
\text { work) from the Internet }\end{array}$ & 600 & 2.25 & 1.22 \\
\hline \multirow[t]{2}{*}{ Writing papers } & $\begin{array}{l}\text { Buying a course paper (or other written work) } \\
\text { from the special companies or classmates }\end{array}$ & 599 & 1.76 & 1.11 \\
\hline & $\begin{array}{l}\text { Writing a paper on one's own, but copying and } \\
\text { pasting some chapters from the Internet }\end{array}$ & 599 & 3.26 & 1.11 \\
\hline $\begin{array}{l}\text { Non-monetary } \\
\text { corruption: }\end{array}$ & $\begin{array}{l}\text { Deceiving a professor while explaining } \\
\text { problems associated with studies }\end{array}$ & 598 & 2.32 & 1.22 \\
\hline $\begin{array}{l}\text { Communicating with } \\
\text { the professor }\end{array}$ & Asking a professor for an individual approach & 600 & 1.62 & 0.98 \\
\hline $\begin{array}{l}\text { Monetary corruption: } \\
\text { Bribe }\end{array}$ & Encountered bribes at universities & 598 & 1.81 & 1.00 \\
\hline
\end{tabular}




\section{Table 2: Descriptive Statistics. Independent scale variables.}

Violation of academic integrity by general perception in the following actions

(from 1 - never to 5 - systematically)

\begin{tabular}{|c|c|c|c|c|}
\hline Areas & Actions & $\begin{array}{l}\text { Observat } \\
\text { ions }\end{array}$ & Mean & $\begin{array}{l}\text { Standard } \\
\text { deviation }\end{array}$ \\
\hline $\begin{array}{l}\text { Non-monetary } \\
\text { corruption: }\end{array}$ & Using a cheat sheet during the exams & 597 & 4.18 & 0.74 \\
\hline Taking exams & $\begin{array}{l}\text { Copying somebody's work during } \\
\text { examinations or tests }\end{array}$ & 594 & 4.07 & 0.84 \\
\hline $\begin{array}{l}\text { Non-monetary } \\
\text { corruption: }\end{array}$ & $\begin{array}{l}\text { Downloading a course paper (or other written } \\
\text { work) from the Internet }\end{array}$ & 595 & 3.56 & 0.96 \\
\hline \multirow[t]{2}{*}{ Writing papers } & $\begin{array}{l}\text { Buying a course paper (or other written work) } \\
\text { from the special companies or classmates }\end{array}$ & 593 & 3.28 & 1.07 \\
\hline & $\begin{array}{l}\text { Writing a paper on one's own, but copying and } \\
\text { pasting some chapters from the Internet }\end{array}$ & 595 & 3.91 & 0.92 \\
\hline $\begin{array}{l}\text { Non-monetary } \\
\text { corruption: }\end{array}$ & $\begin{array}{l}\text { Deceiving a professor while explaining } \\
\text { problems associated with studies }\end{array}$ & 599 & 3.23 & 1.04 \\
\hline $\begin{array}{l}\text { Communicating with } \\
\text { the professor }\end{array}$ & Asking a professor for an individual approach & 598 & 2.60 & 1.13 \\
\hline $\begin{array}{l}\text { Monetary corruption: } \\
\text { Bribe }\end{array}$ & Encountered bribes at universities & 597 & 3.50 & 0.97 \\
\hline \multicolumn{2}{|c|}{ Formal ways of job searching } & 597 & 3.49 & 0.94 \\
\hline
\end{tabular}


Table 3: Descriptive statistics. Independent categorical variables.

\begin{tabular}{|c|c|c|}
\hline Number of cases & Number of cases & 600 \\
\hline \multirow[t]{2}{*}{ Gender } & Male & $57.8 \%$ \\
\hline & Female & $42.2 \%$ \\
\hline \multirow{2}{*}{ Form of education } & State stipend & $71 \%$ \\
\hline & Own costs & $29 \%$ \\
\hline \multirow[t]{7}{*}{ Place of origin } & City, more than $1 \mathrm{mln}$ pop & $9 \%$ \\
\hline & City, 0.5 to $1 \mathrm{mln}$ pop & $13 \%$ \\
\hline & City, 0.25 to $0.5 \mathrm{mln}$ pop & $8.2 \%$ \\
\hline & City, 0.05 to $0.25 \mathrm{mln}$ pop & $13 \%$ \\
\hline & City, 0.02 to $0.05 \mathrm{mln}$ pop & $23.1 \%$ \\
\hline & Small city & $14 \%$ \\
\hline & Village & $19.6 \%$ \\
\hline \multirow{5}{*}{$\begin{array}{l}\text { What are the most frequent marks you } \\
\text { get at the university? }\end{array}$} & Satisfactory & $6.2 \%$ \\
\hline & Between Satisfactory and Good & $19.2 \%$ \\
\hline & Good & $32 \%$ \\
\hline & Between Good and Excellent & $35.8 \%$ \\
\hline & Excellent & $6.8 \%$ \\
\hline \multirow{5}{*}{$\begin{array}{l}\text { How many hours per day do you spend for } \\
\text { self-study/homework/preparation to classes? }\end{array}$} & None & $4.3 \%$ \\
\hline & Less than 1 hour & $16.2 \%$ \\
\hline & $1-2$ hours & $37.5 \%$ \\
\hline & 2-3 hours & $26.7 \%$ \\
\hline & More than 3 hours & $15.2 \%$ \\
\hline \multirow[t]{5}{*}{ Income status of the family } & Enough for food only & $0.5 \%$ \\
\hline & Enough for food and closing & $7.2 \%$ \\
\hline & Not enough for durable goods & $34.7 \%$ \\
\hline & Enough for durable goods & $51 \%$ \\
\hline & Enough for everything & $6.5 \%$ \\
\hline \multirow{4}{*}{$\begin{array}{l}\text { How much do you spend monthly } \\
\text { (housing not included)? }\end{array}$} & Less than $1000 \mathrm{UAH}$ & $42 \%$ \\
\hline & Between 1000 and $1600 \mathrm{UAH}$ & $37.3 \%$ \\
\hline & Between 1600 and $2000 \mathrm{UAH}$ & $13.2 \%$ \\
\hline & More than $2000 \mathrm{UAH}$ & $7.3 \%$ \\
\hline \multirow[t]{3}{*}{ Where do you live? } & Dormitory & $70 \%$ \\
\hline & With parents/relatives & $19.2 \%$ \\
\hline & Rent a flat & $9.5 \%$ \\
\hline \multirow{5}{*}{$\begin{array}{l}\text { What was you External Independent Evaluation } \\
\text { result? }\end{array}$} & Less than 500 & $0.3 \%$ \\
\hline & Between 500 and 600 & $7.2 \%$ \\
\hline & Between 600 and 700 & $41 \%$ \\
\hline & More than 700 & $48 \%$ \\
\hline & Missing & $3.5 \%$ \\
\hline \multirow{4}{*}{$\begin{array}{l}\text { Do you work and, if yes, how many hours per day } \\
\text { is you average working load? }\end{array}$} & Do not work & $77.2 \%$ \\
\hline & Less than 4 hours & $9.7 \%$ \\
\hline & 4-6 hours & $11.7 \%$ \\
\hline & $6-8$ hours & $1.5 \%$ \\
\hline \multirow[t]{2}{*}{ Negative attitude toward corruption } & Negative & $54 \%$ \\
\hline & Other & $46 \%$ \\
\hline \multirow[t]{2}{*}{ HiEd helps to get good education and good job } & Agree & $81.5 \%$ \\
\hline & No & $18.5 \%$ \\
\hline
\end{tabular}


Table 4: PLUM regression estimation results

\begin{tabular}{|c|c|c|c|c|}
\hline \multirow[b]{2}{*}{ Dependent variable } & \multirow{2}{*}{$\begin{array}{l}\text { Monetary } \\
\text { Corruption- } \\
\text { Bribery }\end{array}$} & \multicolumn{3}{|c|}{ Non-monetary corruption } \\
\hline & & $\begin{array}{l}\text { Using a cheat } \\
\text { sheet during } \\
\text { the exams, } \\
\text { personal } \\
\text { experience }\end{array}$ & $\begin{array}{l}\text { Downloading } \\
\text { coursework } \\
\text { from the } \\
\text { Internet, } \\
\text { personal } \\
\text { experience }\end{array}$ & $\begin{array}{l}\text { Buying } \\
\text { coursework } \\
\text { from the special } \\
\text { companies } \\
\text { or classmates, } \\
\text { personal } \\
\text { experience }\end{array}$ \\
\hline Perception of the issue (scale variable) & $\begin{array}{l}0.405^{* * * *} \\
(0.055)\end{array}$ & $\begin{array}{l}0.927 * * * \\
(0.079)\end{array}$ & $\begin{array}{l}0.570 * * * \\
(0.056)\end{array}$ & $\begin{array}{l}0.289 * * * \\
(0.048)\end{array}$ \\
\hline Formal ways of job search (scale variable) & $\begin{array}{l}-0.136^{* *} \\
(0.058) \\
\end{array}$ & $\begin{array}{l}-0.204 * * * \\
(0.064)\end{array}$ & $\begin{array}{l}-0.096 * \\
(0.057) \\
\end{array}$ & $\begin{array}{l}0.005 \\
(0.057) \\
\end{array}$ \\
\hline $\begin{array}{l}\text { Negative attitude toward corruption (dummy } \\
\text { variable) }\end{array}$ & $\begin{array}{l}-0.211 * * \\
(0.097) \\
\end{array}$ & $\begin{array}{l}-0.173 \\
(0.103) \\
\end{array}$ & $\begin{array}{l}-0.094 \\
(0.096)\end{array}$ & $\begin{array}{l}-0.080 \\
(0.096) \\
\end{array}$ \\
\hline $\begin{array}{l}\text { HiEd helps to get good education and good } \\
\text { job (dummy variable) }\end{array}$ & $\begin{array}{l}0.060 \\
(0.131)\end{array}$ & $\begin{array}{l}0.118 \\
(0.147)\end{array}$ & $\begin{array}{l}0.138 \\
(0.133)\end{array}$ & $\begin{array}{l}-0.080 \\
(0.131)\end{array}$ \\
\hline Male Gender (dummy variable) & $\begin{array}{l}0.312 * * * \\
(0.105) \\
\end{array}$ & $\begin{array}{l}-0.327 * * * \\
(0.115) \\
\end{array}$ & $\begin{array}{l}0.178 * \\
(0.105) \\
\end{array}$ & $\begin{array}{l}0.290 * * * \\
(0.106) \\
\end{array}$ \\
\hline State stipend (dummy variable) & $\begin{array}{l}0.051 \\
(0.118)\end{array}$ & $\begin{array}{l}-0.070 \\
(0.130)\end{array}$ & $\begin{array}{l}0.065 \\
(0.118)\end{array}$ & $\begin{array}{l}0.058 \\
(0.117)\end{array}$ \\
\hline \multicolumn{5}{|c|}{ Income status of the family ("Enough for everything" is a reference group): } \\
\hline Enough for food only & $\begin{array}{l}0.882 \\
(0.817)\end{array}$ & $\begin{array}{l}-0.900 \\
(0.847)\end{array}$ & $\begin{array}{l}-0.431 \\
(0.873)\end{array}$ & $\begin{array}{l}-2.362 \\
(15.374)\end{array}$ \\
\hline Enough for food and closing & $\begin{array}{l}0.341 \\
(0.283)\end{array}$ & $\begin{array}{l}0.386 \\
(0.300)\end{array}$ & $\begin{array}{l}-0.140 \\
(0.275)\end{array}$ & $\begin{array}{l}-0.396 \\
(0.275)\end{array}$ \\
\hline Not enough for durable goods & $\begin{array}{l}0.163 \\
(0.223)\end{array}$ & $\begin{array}{l}0.240 \\
(0.228)\end{array}$ & $\begin{array}{l}-0.238 \\
(0.210)\end{array}$ & $\begin{array}{l}-0.262 \\
(0.209)\end{array}$ \\
\hline Enough for durable goods & $\begin{array}{l}0.378 * \\
(0.218) \\
\end{array}$ & $\begin{array}{l}0.163 \\
(0.220) \\
\end{array}$ & $\begin{array}{l}0.140 \\
(0.203) \\
\end{array}$ & $\begin{array}{l}-0.232 \\
(0.202) \\
\end{array}$ \\
\hline \multicolumn{5}{|c|}{ How much do you spend monthly (housing not included)? ("More than 2000 UAH" is a reference group): } \\
\hline Less than $1000 \mathrm{UAH}$ & $\begin{array}{l}-0.270 \\
(0.206)\end{array}$ & $\begin{array}{l}-0.474 * * \\
(0.235)\end{array}$ & $\begin{array}{l}-0.058 \\
(0.206)\end{array}$ & $\begin{array}{l}-0.121 \\
(0.205)\end{array}$ \\
\hline Between 1000 and $1600 \mathrm{UAH}$ & $\begin{array}{l}-0.096 \\
(0.200)\end{array}$ & $\begin{array}{l}-0.628 * * * \\
(0.229)\end{array}$ & $\begin{array}{l}0.065 \\
(0.201)\end{array}$ & $\begin{array}{l}0.038 \\
(0.200)\end{array}$ \\
\hline Between 1600 and $2000 \mathrm{UAH}$ & $\begin{array}{l}0.076 \\
(0.224)\end{array}$ & $\begin{array}{l}-0.235 \\
(0.257)\end{array}$ & $\begin{array}{l}-0.061 \\
(0.226)\end{array}$ & $\begin{array}{l}-0.132 \\
(0.224) \\
\end{array}$ \\
\hline \multicolumn{5}{|c|}{ Where do you live? ("Rent a flat"' is a reference group): } \\
\hline Dormitory & $\begin{array}{l}0.318 * \\
(0.188)\end{array}$ & $\begin{array}{l}0.505 * * * \\
(0.196)\end{array}$ & $\begin{array}{l}0.125 \\
(0.182)\end{array}$ & $\begin{array}{l}0.267 \\
(0.188)\end{array}$ \\
\hline With parents/relatives & $\begin{array}{l}0.149 \\
(0.215)\end{array}$ & $\begin{array}{l}0.362 * \\
(0.220)\end{array}$ & $\begin{array}{l}0.081 \\
(0.205)\end{array}$ & $\begin{array}{l}0.247 \\
(0.212)\end{array}$ \\
\hline \multicolumn{5}{|c|}{ What was you External Independent Evaluation result? ("More than 700" is a reference group): } \\
\hline Less than 500 & $\begin{array}{l}0.503 \\
(0.780)\end{array}$ & $\begin{array}{l}0.438 \\
(0.819)\end{array}$ & $\begin{array}{l}0.341 \\
(0.773)\end{array}$ & $\begin{array}{l}-0.016 \\
(0.766)\end{array}$ \\
\hline Between 500 and 600 & $\begin{array}{l}0.322 \\
(0.210)\end{array}$ & $\begin{array}{l}0.455^{*} \\
(0.248)\end{array}$ & $\begin{array}{l}0.388 * \\
(0.216)\end{array}$ & $\begin{array}{l}0.231 \\
(0.212)\end{array}$ \\
\hline Between 600 and 700 & $\begin{array}{l}0.237 * * \\
(0.113)\end{array}$ & $\begin{array}{l}0.337 * * * \\
(0.124)\end{array}$ & $\begin{array}{l}0.119 \\
(0.114)\end{array}$ & $\begin{array}{l}0.231 * * \\
(0.113)\end{array}$ \\
\hline
\end{tabular}

Do you work and, if yes, how many hours per day is you average working load? ("6-8 hours" is a reference group):

\begin{tabular}{lllll}
\hline Do not work & -0.133 & $-0.861 *$ & $-1.670 * * *$ & -0.493 \\
& $(0.396)$ & $(0.345)$ & $(0.457)$ & $(0.402)$
\end{tabular}




\begin{tabular}{|c|c|c|c|c|}
\hline Less than 4 hours & $\begin{array}{l}-0.240 \\
(0.420)\end{array}$ & $\begin{array}{l}-0.923 * \\
(0.508)\end{array}$ & $\begin{array}{l}-1.944 * * * \\
(0.479)\end{array}$ & $\begin{array}{l}-0.427 \\
(0.317)\end{array}$ \\
\hline 4-6 hours & $\begin{array}{l}0.054 \\
(0.412)\end{array}$ & $\begin{array}{l}-0.792 \\
(0.501)\end{array}$ & $\begin{array}{l}-1.468 * * * \\
(0.471)\end{array}$ & $\begin{array}{l}-0.353 \\
(0.417)\end{array}$ \\
\hline $\begin{array}{l}\text { Do not participate in an NGO or sport club } \\
\text { dummy }\end{array}$ & $\begin{array}{l}-0.132 \\
(0.100)\end{array}$ & $\begin{array}{l}-0.013 \\
(0.110)\end{array}$ & $\begin{array}{l}0.055 \\
(0.100)\end{array}$ & $\begin{array}{l}0.043 \\
(0.100)\end{array}$ \\
\hline \multicolumn{5}{|c|}{ What are the most frequent marks you get at the university? ("Excellent" is a reference group): } \\
\hline Satisfactory & $\begin{array}{l}0.219 \\
(0.296)\end{array}$ & $\begin{array}{l}1.422 * * * \\
(0.345)\end{array}$ & $\begin{array}{l}1.260 * * * \\
(0.310)\end{array}$ & $\begin{array}{l}0.872 * * * \\
(0.301)\end{array}$ \\
\hline Between Satisfactory and Good & $\begin{array}{l}0.179 \\
(0.238)\end{array}$ & $\begin{array}{l}0.653 * * * \\
(0.252)\end{array}$ & $\begin{array}{l}0.522 * * \\
(0.237)\end{array}$ & $\begin{array}{l}0.377 \\
(0.237)\end{array}$ \\
\hline Good & $\begin{array}{l}0.183 \\
(0.220)\end{array}$ & $\begin{array}{l}0.798 * * * \\
(0.230)\end{array}$ & $\begin{array}{l}0.563 * * * \\
(0.218)\end{array}$ & $\begin{array}{l}0.344 \\
(0.220)\end{array}$ \\
\hline Between Good and Excellent & $\begin{array}{l}0.123 \\
(0.210)\end{array}$ & $\begin{array}{l}0.414 * \\
(0.215)\end{array}$ & $\begin{array}{l}0.396 * \\
(0.206)\end{array}$ & $\begin{array}{l}0.232 \\
(0.210)\end{array}$ \\
\hline \multicolumn{5}{|c|}{$\begin{array}{l}\text { How many hours per day do you spend for self study/homework/preparation to classes? ("More than } 3 \\
\text { hour" is a reference group): }\end{array}$} \\
\hline None & $\begin{array}{l}0.833 * * * \\
(0.277)\end{array}$ & $\begin{array}{l}0.887 * * * \\
(0.338)\end{array}$ & $\begin{array}{l}0.979 * * * \\
(0.307)\end{array}$ & $\begin{array}{l}0.779 * * * \\
(0.282)\end{array}$ \\
\hline Less than 1 hour & $\begin{array}{l}0.459 * * \\
(0.197)\end{array}$ & $\begin{array}{l}0.876^{* * * *} \\
(0.220)\end{array}$ & $\begin{array}{l}0.707 * * * \\
(0.196)\end{array}$ & $\begin{array}{l}0.496 * * \\
(0.194)\end{array}$ \\
\hline $1-2$ hours & $\begin{array}{l}0.288^{*} \\
(0.161)\end{array}$ & $\begin{array}{l}0.572 * * * \\
(0.169)\end{array}$ & $\begin{array}{l}0.322 * \\
(0.156)\end{array}$ & $\begin{array}{l}0.208 \\
(0.186)\end{array}$ \\
\hline $2-3$ hours & $\begin{array}{l}0.252 \\
(0.165) \\
\end{array}$ & $\begin{array}{l}0.317 * \\
(0.170) \\
\end{array}$ & $\begin{array}{l}0.160 \\
(0.159) \\
\end{array}$ & $\begin{array}{l}0.094 \\
(0.162) \\
\end{array}$ \\
\hline \multicolumn{5}{|c|}{ Place of origin ("Village" is a reference group): } \\
\hline City, more than $1 \mathrm{mln}$ pop & $\begin{array}{l}-0.481 * \\
(0.255)\end{array}$ & $\begin{array}{l}-0.213 \\
(0.267)\end{array}$ & $\begin{array}{l}-0.792 * * * \\
(0.247)\end{array}$ & $\begin{array}{l}-0.366 \\
(0.252)\end{array}$ \\
\hline City, 0.5 to $1 \mathrm{mln}$ pop & $\begin{array}{l}-0.476^{* *} \\
(0.204)\end{array}$ & $\begin{array}{l}-0.268 \\
(0.211)\end{array}$ & $\begin{array}{l}-0.172 \\
(0.196)\end{array}$ & $\begin{array}{l}0.442 * * \\
(0.199)\end{array}$ \\
\hline City, 0.25 to $0.5 \mathrm{mln}$ pop & $\begin{array}{l}-0.009 \\
(0.204)\end{array}$ & $\begin{array}{l}0.001 \\
(0.225)\end{array}$ & $\begin{array}{l}0.256 \\
(0.209)\end{array}$ & $\begin{array}{l}0.276 \\
(0.207)\end{array}$ \\
\hline City, 0.05 to $0.25 \mathrm{mln}$ pop & $\begin{array}{l}-0.233 \\
(0.171)\end{array}$ & $\begin{array}{l}-0.036 \\
(0.190)\end{array}$ & $\begin{array}{l}0.071 \\
(0.172)\end{array}$ & $\begin{array}{l}0.527 * * * \\
(0.172)\end{array}$ \\
\hline City, 0.02 to $0.05 \mathrm{mln}$ pop & $\begin{array}{l}0.090 \\
(0.146)\end{array}$ & $\begin{array}{l}0.049 \\
(0.164)\end{array}$ & $\begin{array}{l}0.098 \\
(0.148)\end{array}$ & $\begin{array}{l}0.205 \\
(0.148)\end{array}$ \\
\hline Small city & $\begin{array}{l}0.060 \\
(0.163)\end{array}$ & $\begin{array}{l}0.055 \\
(0.184)\end{array}$ & $\begin{array}{l}-0.054 \\
(0.165)\end{array}$ & $\begin{array}{l}0.273^{*} \\
(0.165)\end{array}$ \\
\hline Constant, threshold & Yes & Yes & Yes & Yes \\
\hline Link function & Comp. Log-log & $\begin{array}{l}\text { Comp. Log- } \\
\log \end{array}$ & Comp. Log-log & Comp. Log-log \\
\hline Goodness of fit, Pearson test p-value & 1.000 & 0.014 & 0.072 & 0.000 \\
\hline Cox\&Snell Pseudo R^2 & 0.751 & 0.484 & 0.557 & 0.365 \\
\hline
\end{tabular}

Ordinal regression using PLUM procedure in SPSS. ***, ** and * indicate significance at the 1, 5 and 10 percent level, respectively. 


\begin{tabular}{|c|c|c|c|c|}
\hline \multirow{3}{*}{ Dependent variable } & \multicolumn{4}{|c|}{ Non-monetary Corruption } \\
\hline & & & Deceiving a & \\
\hline & $\begin{array}{l}\text { Copying some parts } \\
\text { of a course paper } \\
\text { from the Internet, } \\
\text { personal experience }\end{array}$ & $\begin{array}{l}\text { Copying } \\
\text { somebody's } \\
\text { work during } \\
\text { examinations } \\
\text { or tests, } \\
\text { personal } \\
\text { experience }\end{array}$ & $\begin{array}{l}\text { professor } \\
\text { while } \\
\text { explaining } \\
\text { problems } \\
\text { associated with } \\
\text { studies, } \\
\text { personal } \\
\text { experience }\end{array}$ & $\begin{array}{l}\text { Asking a } \\
\text { professor for an } \\
\text { individual } \\
\text { treatment, } \\
\text { personal } \\
\text { experience }\end{array}$ \\
\hline Perception of the issue (scale variable) & $\begin{array}{l}0.575 * * * \\
(0.094) \\
\end{array}$ & $\begin{array}{l}0.657 * * * \\
(0.066) \\
\end{array}$ & $\begin{array}{l}0.854 * * * \\
(0.089) \\
\end{array}$ & $\begin{array}{l}0.357 * * * \\
(0.047) \\
\end{array}$ \\
\hline $\begin{array}{l}\text { Formal ways of job search (scale } \\
\text { variable) }\end{array}$ & $\begin{array}{l}-0.011 \\
(0.097)\end{array}$ & $\begin{array}{l}-0.158 * * \\
(0.063)\end{array}$ & $\begin{array}{l}0.040 \\
(0.098) \\
\end{array}$ & $\begin{array}{l}-0.014 \\
(0.058) \\
\end{array}$ \\
\hline $\begin{array}{l}\text { Negative attitude toward corruption } \\
\text { (dummy variable) }\end{array}$ & $\begin{array}{l}-0.357 * * \\
(0.162)\end{array}$ & $\begin{array}{l}-0.296 * * * \\
(0.106) \\
\end{array}$ & $\begin{array}{l}-0.100 \\
(0.165)\end{array}$ & $\begin{array}{l}-0.192 * * \\
(0.097)\end{array}$ \\
\hline $\begin{array}{l}\text { HiEd helps to get good education and } \\
\text { good job (dummy variable) }\end{array}$ & $\begin{array}{l}-0.362 * \\
(0.221) \\
\end{array}$ & $\begin{array}{l}-0.222 \\
(0.148) \\
\end{array}$ & $\begin{array}{l}-0.319 \\
(0.221) \\
\end{array}$ & $\begin{array}{l}-0.196 \\
(0.130) \\
\end{array}$ \\
\hline Male Gender (dummy variable) & $\begin{array}{l}0.143 \\
(0.174)\end{array}$ & $\begin{array}{l}-0.156 \\
(0.114)\end{array}$ & $\begin{array}{l}0.319 * \\
(0.179)\end{array}$ & $\begin{array}{l}0.177 * \\
(0.106)\end{array}$ \\
\hline State stipend (dummy variable) & $\begin{array}{l}-0.227 \\
(0.198)\end{array}$ & $\begin{array}{l}-0.069 \\
(0.132)\end{array}$ & $\begin{array}{c}-0.248 \\
(0.199)\end{array}$ & $\begin{array}{l}0.012 \\
(0.119)\end{array}$ \\
\hline \multicolumn{5}{|c|}{ Income status of the family ("Enough for everything" is a reference group): } \\
\hline Enough for food only & $\begin{array}{l}0.819 \\
(1.363)\end{array}$ & $\begin{array}{l}-0.354 \\
(0.836)\end{array}$ & $\begin{array}{l}-0.168 \\
(0.873)\end{array}$ & $\begin{array}{l}0.124 \\
(0.801)\end{array}$ \\
\hline Enough for food and closing & $\begin{array}{l}0.191 \\
(0.459)\end{array}$ & $\begin{array}{l}0.227 \\
(0.300)\end{array}$ & $\begin{array}{l}-1.083^{* *} \\
(0.482)\end{array}$ & $\begin{array}{l}-0.443 \\
(0.275)\end{array}$ \\
\hline Not enough for durable goods & $\begin{array}{l}0.649 * \\
(0.356)\end{array}$ & $\begin{array}{l}0.427 * \\
(0.235)\end{array}$ & $\begin{array}{l}-0.487 \\
(0.173)\end{array}$ & $\begin{array}{l}-0.464 \\
(0.209)\end{array}$ \\
\hline Enough for durable goods & $\begin{array}{l}0.447 \\
(0.344)\end{array}$ & $\begin{array}{l}0.168 \\
(0.227)\end{array}$ & $\begin{array}{l}-0.172 \\
(0.344)\end{array}$ & $\begin{array}{l}-0.229 \\
(0.201)\end{array}$ \\
\hline \multicolumn{5}{|c|}{ How much do you spend monthly (housing not included)? ("More than 2000 UAH" is a reference group): } \\
\hline Less than $1000 \mathrm{UAH}$ & $\begin{array}{l}-0.608 * \\
(0.346)\end{array}$ & $\begin{array}{l}-0.348 \\
(0.240)\end{array}$ & $\begin{array}{l}0.392 \\
(0.353)\end{array}$ & $\begin{array}{l}-0.194 \\
(0.204)\end{array}$ \\
\hline Between 1000 and $1600 \mathrm{UAH}$ & $\begin{array}{l}-0.863 * * \\
(0.339)\end{array}$ & $\begin{array}{l}-0.562 * * \\
(0.235)\end{array}$ & $\begin{array}{l}0.276 \\
(0.343)\end{array}$ & $\begin{array}{l}-0.259 \\
(0.200)\end{array}$ \\
\hline Between 1600 and $2000 \mathrm{UAH}$ & $\begin{array}{l}-0.214 \\
(0.378) \\
\end{array}$ & $\begin{array}{l}-0.235 \\
(0.260) \\
\end{array}$ & $\begin{array}{l}0.445 \\
(0.384) \\
\end{array}$ & $\begin{array}{l}-0.247 \\
(0.225) \\
\end{array}$ \\
\hline \multicolumn{5}{|c|}{ Where do you live? ("Rent a flat"' is a reference group): } \\
\hline Dormitory & $\begin{array}{l}0.440 \\
(0.306)\end{array}$ & $\begin{array}{l}0.291 \\
(0.198)\end{array}$ & $\begin{array}{l}-0.215 \\
(0.311)\end{array}$ & $\begin{array}{l}-0.147 \\
(0.188)\end{array}$ \\
\hline With parents/relatives & $\begin{array}{l}0.168 \\
(0.339)\end{array}$ & $\begin{array}{l}0.264 \\
(0.220)\end{array}$ & $\begin{array}{l}0.306 \\
(0.350)\end{array}$ & $\begin{array}{l}0.335 \\
(0.211)\end{array}$ \\
\hline \multicolumn{5}{|c|}{ What was you External Independent Evaluation result? ("More than 700" is a reference group): } \\
\hline Less than 500 & $\begin{array}{l}1.698 \\
(1.359)\end{array}$ & $\begin{array}{l}0.267 \\
(0.858)\end{array}$ & $\begin{array}{l}1.997 \\
(1.318)\end{array}$ & $\begin{array}{l}0.230 \\
(0.770)\end{array}$ \\
\hline Between 500 and 600 & $\begin{array}{l}0.654 * \\
(0.362)\end{array}$ & $\begin{array}{l}0.405 \\
(0.250)\end{array}$ & $\begin{array}{l}-0.080 \\
(0.356)\end{array}$ & $\begin{array}{l}-0.242 \\
(0.213)\end{array}$ \\
\hline Between 600 and 700 & $\begin{array}{l}0.084 \\
(0.188) \\
\end{array}$ & $\begin{array}{l}0.196 \\
(0.124) \\
\end{array}$ & $\begin{array}{l}-0.236 \\
(0.192) \\
\end{array}$ & $\begin{array}{l}-0.132 \\
(0.114) \\
\end{array}$ \\
\hline
\end{tabular}

Do you work and, if yes, how many hours per day is you average working load? ("6-8 hours" is a reference group):

Perception of the issue (scale
Formal ways of job search (sca
variable)
Negative attitude toward corrupt
(dummy variable)
HiEd helps to get good educat
good job (dummy variable)
Male Gender (dummy variable)
State stipend (dummy variable)
Income status of the family ('
Enough for food only

Do not work

$$
-0.474
$$$$
\text { (0.679) }
$$

-0.699
$(0.498)$

$-0.213$

(0.684)
$-0.229$

(0.407) 


\begin{tabular}{|c|c|c|c|c|}
\hline Less than 4 hours & $\begin{array}{l}-0.769 \\
(0.715)\end{array}$ & $\begin{array}{l}-0.817 \\
(0.520)\end{array}$ & $\begin{array}{l}-0.529 \\
(0.722)\end{array}$ & $\begin{array}{l}-0.495 \\
(0.432)\end{array}$ \\
\hline 4-6 hours & $\begin{array}{l}0.022 \\
(0.706)\end{array}$ & $\begin{array}{l}-0.188 \\
(0.513)\end{array}$ & $\begin{array}{l}-0.134 \\
(0.710)\end{array}$ & $\begin{array}{l}0.037 \\
(0.421)\end{array}$ \\
\hline $\begin{array}{l}\text { Do not participate in an NGO or sport } \\
\text { club dummy }\end{array}$ & $\begin{array}{l}0.132 \\
(0.167)\end{array}$ & $\begin{array}{l}-0.080 \\
(0.110)\end{array}$ & $\begin{array}{l}0.048 \\
(0.172)\end{array}$ & $\begin{array}{l}-0.001 \\
(0.101)\end{array}$ \\
\hline \multicolumn{5}{|c|}{ What are the most frequent marks you get at the university? ("Excellent" is a reference group): } \\
\hline Satisfactory & $\begin{array}{l}0.564 \\
(0.494)\end{array}$ & $\begin{array}{l}0.662 * * \\
(0.328)\end{array}$ & $\begin{array}{l}1.583 * * * \\
(0.515)\end{array}$ & $\begin{array}{l}0.555^{*} \\
(0.305)\end{array}$ \\
\hline Between Satisfactory and Good & $\begin{array}{l}-0.029 \\
(0.290)\end{array}$ & $\begin{array}{l}0.314 \\
(0.250)\end{array}$ & $\begin{array}{l}0.869 * * \\
(0.414)\end{array}$ & $\begin{array}{l}0.550 * * \\
(0.246)\end{array}$ \\
\hline Good & $\begin{array}{l}0.008 \\
(0.358)\end{array}$ & $\begin{array}{l}0.357 \\
(0.226)\end{array}$ & $\begin{array}{l}1.146 * * * \\
(0.384)\end{array}$ & $\begin{array}{l}0.534 * * \\
(0.227)\end{array}$ \\
\hline Between Good and Excellent & $\begin{array}{l}0.205 \\
(0.229) \\
\end{array}$ & $\begin{array}{l}-0.033 \\
(0.211) \\
\end{array}$ & $\begin{array}{l}0.444 \\
(0.366) \\
\end{array}$ & $\begin{array}{l}0.422 * \\
(0.217) \\
\end{array}$ \\
\hline \multicolumn{5}{|c|}{$\begin{array}{l}\text { How many hours per day do you spend for self-study/homework/preparation to classes? ("More than } 3 \text { hour" } \\
\text { is a reference group): }\end{array}$} \\
\hline None & $\begin{array}{l}0.537 \\
(0.462)\end{array}$ & $\begin{array}{l}0.896 * * * \\
(0.329)\end{array}$ & $\begin{array}{l}1.801 * * * \\
(0.477)\end{array}$ & $\begin{array}{l}0.525^{*} \\
(0.279)\end{array}$ \\
\hline Less than 1 hour & $\begin{array}{l}1.195 * * * \\
(0.329)\end{array}$ & $\begin{array}{l}0.959 * * * \\
(0.219)\end{array}$ & $\begin{array}{l}1.441 * * * \\
(0.341)\end{array}$ & $\begin{array}{l}0.557 * * * \\
(0.199)\end{array}$ \\
\hline $1-2$ hours & $\begin{array}{l}0.981 * * * \\
(0.264)\end{array}$ & $\begin{array}{l}0.793 * * * \\
(0.167)\end{array}$ & $\begin{array}{l}0.776 * * * \\
(0.280)\end{array}$ & $\begin{array}{l}0.278 * \\
(0.161)\end{array}$ \\
\hline 2-3 hours & $\begin{array}{l}0.732 * * * \\
(0.270) \\
\end{array}$ & $\begin{array}{l}0.491 * * * \\
(0.168) \\
\end{array}$ & $\begin{array}{l}0.437 \\
(0.286) \\
\end{array}$ & $\begin{array}{l}-0.008 \\
(0.166) \\
\end{array}$ \\
\hline \multicolumn{5}{|c|}{ Place of origin("Village" is a reference group): } \\
\hline City, more than $1 \mathrm{mln}$ pop & $\begin{array}{l}-0.102 \\
(0.407)\end{array}$ & $\begin{array}{l}-0.543 * * \\
(0.263)\end{array}$ & $\begin{array}{l}-0.387 \\
(0.416)\end{array}$ & $\begin{array}{l}-0.891 * * * \\
(0.255)\end{array}$ \\
\hline City, 0.5 to $1 \mathrm{mln}$ pop & $\begin{array}{l}0.112 \\
(0.331)\end{array}$ & $\begin{array}{l}-0.009 \\
(0.212)\end{array}$ & $\begin{array}{l}-0.700 * * \\
(0.339)\end{array}$ & $\begin{array}{l}-0.314 \\
(0.201)\end{array}$ \\
\hline City, 0.25 to $0.5 \mathrm{mln}$ pop & $\begin{array}{l}0.526 \\
(0.350)\end{array}$ & $\begin{array}{l}0.184 \\
(0.230)\end{array}$ & $\begin{array}{l}0.222 \\
(0.352)\end{array}$ & $\begin{array}{l}0.160 \\
(0.208)\end{array}$ \\
\hline City, 0.05 to $0.25 \mathrm{mln}$ pop & $\begin{array}{l}0.348 \\
(0.288)\end{array}$ & $\begin{array}{l}0.396 * * \\
(0.193)\end{array}$ & $\begin{array}{l}0.038 \\
(0.292)\end{array}$ & $\begin{array}{l}0.127 \\
(0.172)\end{array}$ \\
\hline City, 0.02 to $0.05 \mathrm{mln}$ pop & $\begin{array}{l}0.396 \\
(0.250)\end{array}$ & $\begin{array}{l}0.251 \\
(0.162)\end{array}$ & $\begin{array}{l}-0.166 \\
(0.253)\end{array}$ & $\begin{array}{l}0.040 \\
(0.148)\end{array}$ \\
\hline Small city & $\begin{array}{l}-0.087 \\
(0.267)\end{array}$ & $\begin{array}{l}-0.016 \\
(0.178)\end{array}$ & $\begin{array}{l}-0.227 \\
(0.285)\end{array}$ & $\begin{array}{l}-0.056 \\
(0.168)\end{array}$ \\
\hline Constant, threshold & Yes & Yes & Yes & Yes \\
\hline Link function & Logit & $\begin{array}{l}\text { Comp. Log- } \\
\log \end{array}$ & Logit & Comp. Log-log \\
\hline Goodness of fit, Pearson test p-value & 0.000 & 0.000 & 0.000 & 0.000 \\
\hline Cox\&Snell Pseudo R^2 & 0.190 & 0.374 & 0.314 & 0.298 \\
\hline
\end{tabular}

Ordinal regression using PLUM procedure in SPSS. ***,** and * indicate significance at the 1, 5 and 10 percent level, respectively. 